\title{
DIFFERENCES BETWEEN THE FEVER OF STILL'S DISEASE AND THAT OF RHEUMATIC FEVER
}

\author{
BY
}

\author{
F. J. MCMINN AND E. G. L. BYWATERS
}

From the Rheumatism Research Unit (M.R.C.), Canadian Red Cross Memorial Hospital, Taplow, Berks.

In the last 12 years' observation of a series of over 1,000 cases of rheumatic fever, over 200 cases of Still's disease, and other less common "connective tissue diseases" in children, we have come to place some diagnostic value on the character of the fever. Our impression has been that, in Still's disease, and, much less commonly, in a few cases of adult rheumatoid arthritis, the body temperature chart shows a large daily swing, reaching high levels at night and coming down to below $98 \cdot 4^{\circ} \mathrm{F}$. by morning, often over prolonged periods, whereas in rheumatic fever the temperature, though equally high, is more stable and shows much less swing. However, there seem to be many exceptions to this general impression and we have therefore undertaken a detailed survey of this question.

\section{Material}

The charts of all patients diagnosed as having Still's disease up to the age of 16 at the time of admission were surveyed and all cases were selected who showed a period of fever (as defined below) during one week of their hospital admission, when they were not receiving anti-pyretic treatment. Fifty cases were thus selected out of a total of something over 200. From the patients with rheumatic fever admitted over the same period, the middle 4-year intake was surveyed and fifty cases were chosen in the same way, i.e. these cases showed fever (as defined below) while being treated with bed rest alone without specific anti-pyretic drugs for a period of at least one week. This was possible because during this time the effects of bed rest alone in rheumatic fever were being studied. In each instance, no salicylate or steroid therapy had been given for at least 4 days before the study and none was given during the period of study. In some children, codeine phosphate was administered when needed to control pain.
For the purpose of this study, fever was defined as an oral temperature record of $99.4^{\circ} \mathrm{F}$. or more on two occasions in the 7 days, or of $100.4^{\circ} \mathrm{F}$. on one or more occasions. Temperatures were read by the nursing staff to an accuracy of $0 \cdot 2^{\circ} \mathrm{F}$. at 4-hourly intervals during periods of fever. The thermometers had previously been checked in the laboratory.

All cases in the rheumatic fever group satisfied the criteria set up by the American Heart Association, viz.: one major and two minor manifestations, listed as follows:

\begin{tabular}{|c|c|}
\hline Major & Minor \\
\hline Carditis & Fever \\
\hline Polyarthritis & Elevated sedimentation rate \\
\hline Chorea & Increased $\mathrm{P}-\mathrm{R}$ interval \\
\hline Nodules & $\begin{array}{l}\text { Evidence of recent streptococcal } \\
\text { infection }\end{array}$ \\
\hline $\begin{array}{l}\text { Erythema } \\
\text { marginatum }\end{array}$ & $\begin{array}{l}\text { Reliable history of rheumatic fever } \\
\text { or evidence of pre-existing rheu- } \\
\text { matic heart disease. }\end{array}$ \\
\hline
\end{tabular}

All such patients were between the ages of 4 and 16. Still's disease was defined as a chronic polyarthritis with onset below the age of 16 years without evidence of other disease, such as tuberculosis, ankylosing spondylitis, disseminated lupus erythematosus, or ulcerative colitis, on their follow-up record. Arthritis was considered to be present if any two of the following triad were present: pain, swelling, or limitation of movement.

Of the group with Still's disease 47 patients filled these criteria, and three were cases of monarticular arthritis in which the diagnosis was established as the result of joint biopsy. The children were all aged between 2 and 16 years at the time of study.

During the 7-day period of maximal fever, which was usually within the first week of hospital admission, estimates were made for each case of the 
maximum daily swing in temperature during the week, the mean maximum and minimum daily temperatures over a period of one week, the maximum temperature reached during the week, and the general pattern of the temperature chart. Erythrocyte sedimentation rates were estimated during this week by the Westergren method and correlation made with temperature.

\section{Results}

The results are given in Tables I, II, and III. The maximum temperature during the week, the maximum daily swing of temperature for each case during
TABLE III

MEAN HIGHEST INDIVIDUAL TEMPERATURE DURING THE WEEK

\begin{tabular}{|c|c|c|}
\hline \multirow{2}{*}{$\begin{array}{c}\text { Erythrocyte } \\
\text { Sedimentation Rate } \\
(\mathrm{mm} . / \mathrm{hr})\end{array}$} & \multicolumn{2}{|c|}{ Body Temperature $\left({ }^{\circ} \mathrm{F}.\right)$} \\
\hline & Still's Disease & Rheumatic Fever \\
\hline $\begin{array}{c}0-50 \\
51-100 \\
100\end{array}$ & $\begin{array}{l}101 \cdot 9 \\
102 \cdot 6 \\
101 \cdot 4\end{array}$ & $\begin{array}{l}100 \cdot 7 \\
101 \cdot 5 \\
102 \cdot 4\end{array}$ \\
\hline Total & $102 \cdot 3 \pm 1 \cdot 63^{\circ} \mathrm{F}$ & $101 \cdot 4 \pm 1 \cdot 31$ \\
\hline
\end{tabular}

$$
C=\frac{0 \cdot 9}{0 \cdot 24}=3 \cdot 75 \quad P=<0.001
$$

TABLE I

MEAN MAXIMUM DAILY SWING DURING ONE WEEK IN JUVENILE RHEUMATOID ARTHRITIS AND RHEUMATIC FEVER

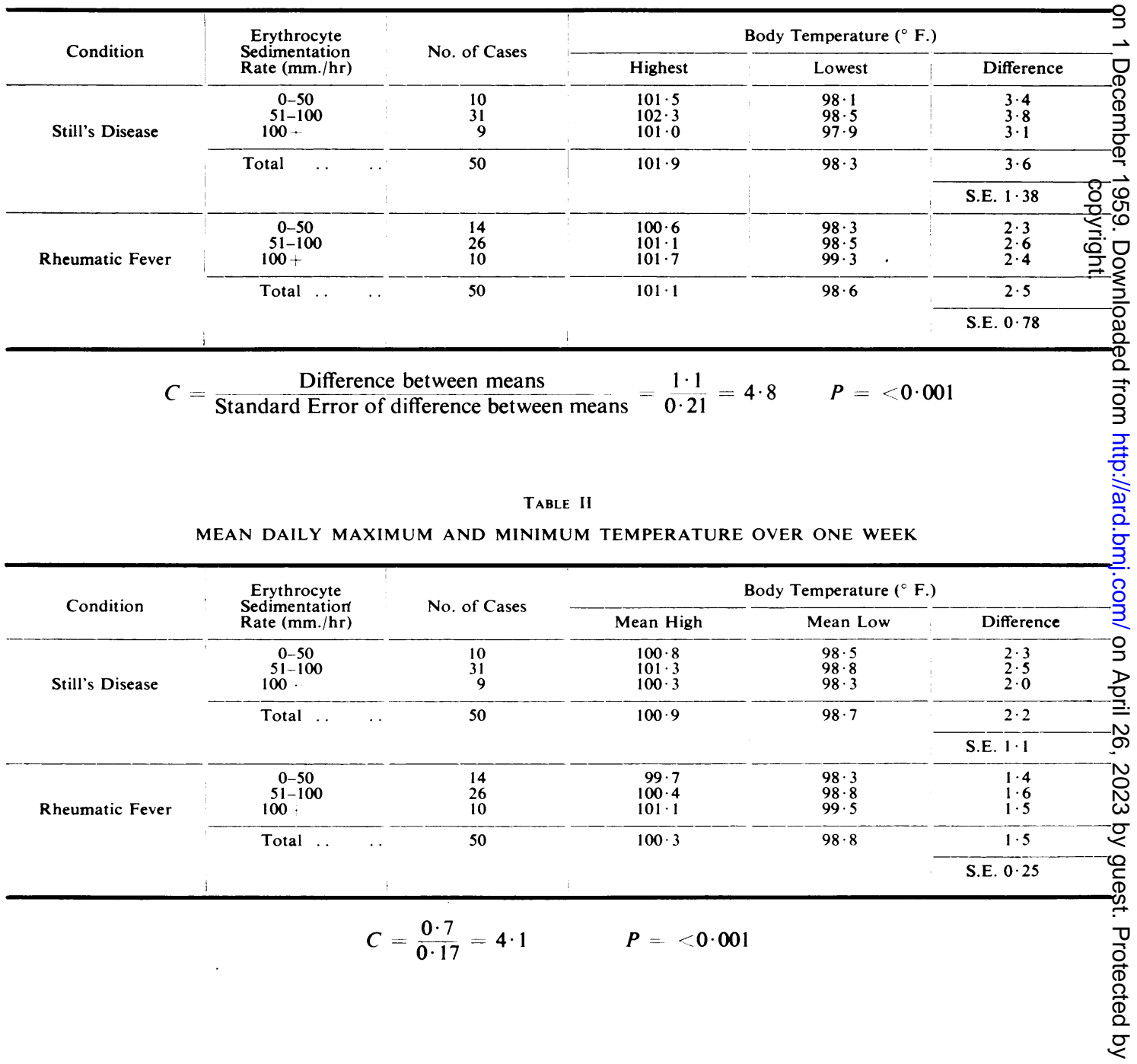


the week, and the mean maximum weekly temperature are seen to be higher in cases of Still's disease than in rheumatic fever. In these febrile cases of Still's disease there appears to be little correlation between the temperature and the erythrocyte sedimentation rate. In febrile rheumatic fever, however, the temperatures are seen to be higher with an increased erythrocyte sedimentation rate, and in cases in which the erythrocyte sedimentation rate is over $100 \mathrm{~mm} . / \mathrm{hr}$ the temperature in rheumatic fever is higher than in Still's disease. In rheumatic fever, although the temperature is higher with an increased erythrocyte sedimentation rate, there is no increase in temperature swing, but in Still's disease the temperature swing is greater. Finally, the temperature swing in Still's disease is significantly greater than that in rheumatic fever.

Fig. 1 illustrates the temperature (maximum and minimum daily temperatures) in four cases of Still's disease (top) contrasted with four cases of rheumatic fever (bottom). On the left is the typical temperature chart, in the middle two less typical charts and on the far right the most atypical pattern encountered in each two series.

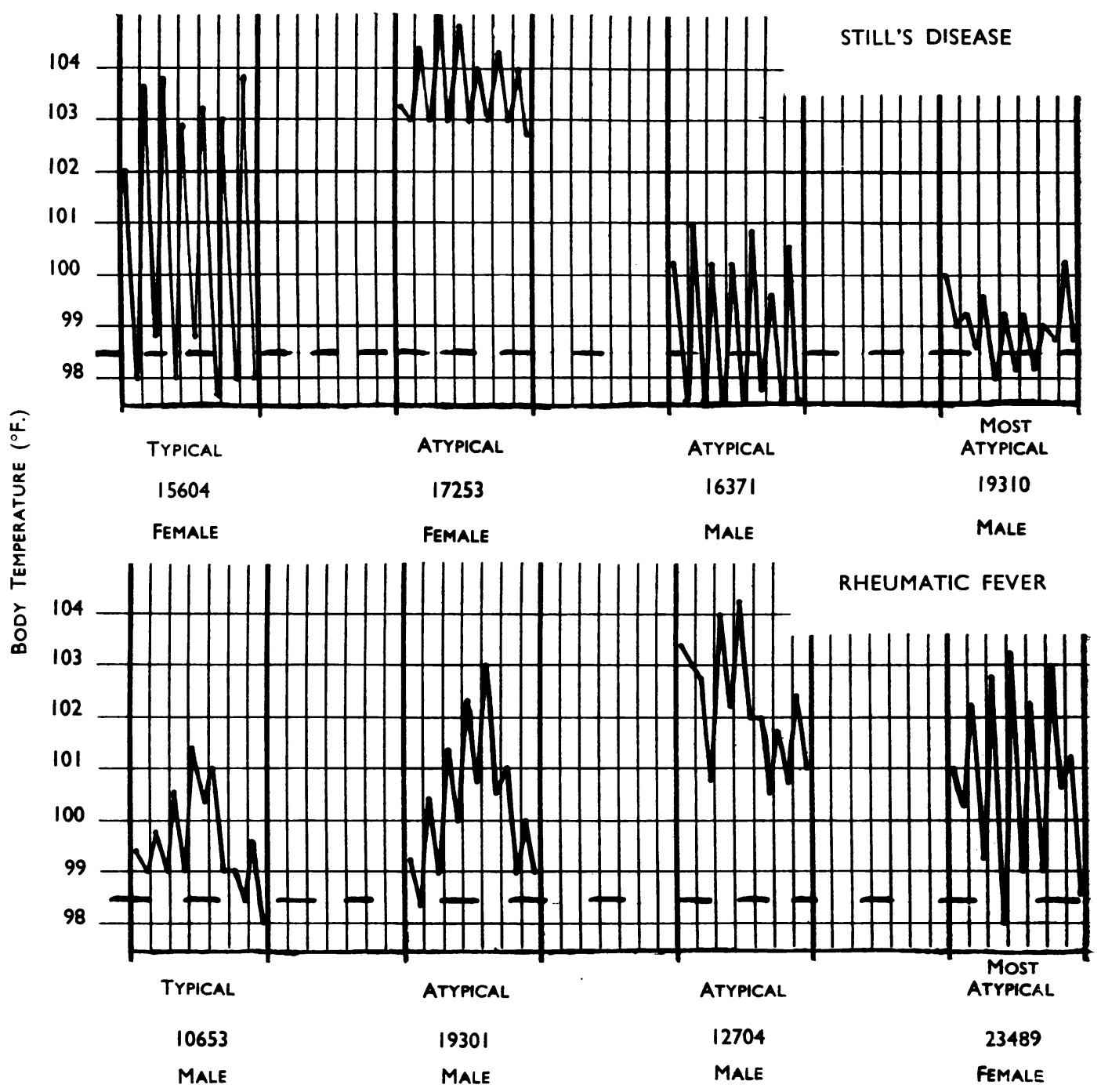

Fig. 1.-Temperature records for weekly periods in Still's disease (top) and rheumatic fever (bottom). 


\section{Discussion}

These results bear out our impressions that, in children with fever and polyarthritis, temperature patterns showing high maximum levels and large swings are more usually due to Still's disease than to rheumatic fever. This is of diagnostic importance, and has been used to establish the diagnosis in obscure cases in which there was no other differentiating feature. (Differentiation is important for practical reasons, because of the prophylactic antibiotic drugs that can be given in cases of rheumatic fever.) However, exceptions are not infrequent. It is worth emphasizing (Fig. 2) that salicylates given in adequate dosage will abolish fever as much in Still's disease as in rheumatic fever. This measure is not, therefore, as some have continued to claim, of diagnostic help. The degree of fever suppression seems to depend upon the amount of salicylates given, since under a certain critical dosage escape occurs and fever returns. It is also worth remarking that the fever of Still's disease is quite frequently accompanied by the typical rash towards evening (Isdale and Bywaters, 1956), and this may sometimes also be seen in febrile adult patients; it is not always dependent on fever.

We have not dealt in this study with the course of fever. It should be emphasized that, in the absence $\frac{}{3}$ of anti-pyretic treatment, fever may be prolonged in Still's disease, whereas it is usually of comparativelyọ short duration in rheumatic fever, except in cases $\Rightarrow$ with cyclical attacks. That hyperpyrexia in rheumatic fever is now seldom seen (Miller, 1923) is? probably due to the fact that less heroic doses of $\frac{\overline{\bar{n}}}{\bar{n}}$ salicylates are given than in the late 19th century. $\frac{\bar{\rho}}{\bar{D}}$ Salicylates increase the basal metabolic rate and this $\underset{\mathcal{Q}}{ }$ may offset their effect on temperature regulation: it is probable that the epidemic of hyperpyrexia seen in the 19th century soon after the introduction of salicyl compounds was due to excess medication. $\vec{\omega}$ We have seen hyperpyrexia in rheumatic fever only rarely, and then associated with high salicylate dosage, whereas in Still's disease high fevers of $105 \stackrel{\vec{\circ}}{\circ}$ and 106 occur not uncommonly in the absence of salicylate medication, and may lead, as in lupusin erythematosus and other conditions with high fever, $\mathscr{\omega}$ to loss of hair.

\section{Summary}

The fever in fifty cases of rheumatic fever is com- $\mathbb{D}$ pared with that in fifty cases of Still's disease. A® study of the height of temperature, the temperatureo swing, and the correlation with the erythrocyte ${ }^{\mathbb{D}}$ sedimentation rate showed that the temperatuseco

Fig. 2.-Effect of aspirin medication on the fever of Still's disease for a period of $3 !$ weeks. Note escape when dosage is reduced. 
swing is greater in Still's disease, and that there is a direct correlation between height of temperature and erythrocyte sedimentation rate in rheumatic fever, but not in Still's disease.

\section{REFERENCES}

Isdale, I. C., and Bywaters, E. G. L. (1956). Quart. J. Med., 25, 377. Miller, R. (1923). Brit. med. J., 2, 702.

\section{Différence entre la fièvre dans la maladie de Still et dans la maladie de Bouillaud}

\section{RÉSUMÉ}

On compara la fièvre dans 50 cas de maladie de Bouillaud à celle dans 50 cas de maladie de Still. L'étude de l'élévation de la température et de ses oscillations, ainsi que sa corrélation avec la vitesse de sédimentation érythrocytaire révéla que l'oscillation pyrétique est plus prononcée dans la maladie de Still et qu'il y a un rapport direct entre la montée pyrétique et la vitesse de sédimentation érythrocytaire dans la maladie de Bouillaud, mais non pas dans la maladie de Still.

\section{Diferencia entre la fiebre en la enfermedad de Still y en el reumatismo poliarticular agudo}

\section{Sumario}

Se comparó la fiebre en 50 casos de reumatismo poliarticular agudo a la en 50 casos de enfermedad de Still. El estudio de la elevación de la temperatura y de sus oscilaciones, así como su correlación con la velocidad de sedimentación eritrocitaria mostró que la oscilación pirética es más pronunciada en la enfermedad de Still y que hay una correlación directa entre la subida de la temperatura y la velocidad de sedimentación eritrocitaria en el reumatismo articular agudo, pero no hay tal correlación en la enfermedad de Still. 